\title{
ANALISIS INDEKS KEPUASAN MASYARAKAT DI KANTOR DINAS KEPENDUDUKAN DAN PENCATATAN SIPIL KOTA PALANGKA RAYA
}

\author{
Mahda Cahyati Ningrum ${ }^{a}$, Bhayu Rhama ${ }^{b}$, Imanuel Jaya ${ }^{c}$ \\ ${ }^{a}$ University of Palangka Raya, Faculty of Social and Politics, Department of Public Administration, \\ Yos Sudarso Street, Palangka Raya, Indonesia, \\ Email: mahdacahyati@gmail.com \\ ${ }^{b}$ University of Palangka Raya, Faculty of Social and Politics, Department of Public Administration, \\ Yos Sudarso Street, Palangka Raya, Indonesia, \\ Email:bhayurhama@fisip.upr.ac.id \\ ${ }^{c}$ University of Palangka Raya, Faculty of Social and Politics, Department of Public Administration, \\ Yos Sudarso Street, Palangka Raya, Indonesia, \\ Email: jaya_suhin@yahoo.com
}

\begin{abstract}
ABSTRAK
Pelayanan publik yang berkualitas adalah pelayanan yang mampu memenuhi harapan dan melampaui harapan-harapan dari masyarakat yang dilayani. Beberapa masyarakat mengeluhkan pelayanan publik yang diberikan oleh Kantor Dinas Kependudukan dan Pencatatan Sipil Kota Palangka Raya. Penelitian ini bertujuan untuk menganalisis indeks kepuasan masyarakat terhadap pelayanan publik di Kantor Dinas Kependudukan dan Pencatatan Sipil Kota Palangka Raya yang mengacu pada Kepmenpan Nomor 25 Tahun 2004 dengan menggunakan teori dimensi SERVQUAL oleh Zeithaml et.al (1990) yaitu terdiri dari dimensi tangible (berwujud), reliability (kehandalan), responsiveness (respon/ketanggapan), assurance (jaminan), dan empathy (empati).

Metode yang digunakan dalam penelitian ini adalah penelitian kuantitatif deskriptif dengan menggunakan pendekatan metode survey. Teknik pengambilan sampel menggunakan teknik non probability sampling dengan jenis accidental sampling. Jumlah sampel dalam penelitian ini adalah 100 responden. Teknik pengumpulan data dilakukan dengan cara observasi, kuesioner (angket) dan dokumentasi.

Hasil penelitian menunjukkan bahwa nilai indeks kepuasan masyarakat di Kantor Dinas Kependudukan dan Pencatatan Sipil Kota Palangka Raya adalah sebesar 2,963 dan nilai indeks kepuasan masyarakat setelah dikonversikan sebesar 74,075 dengan mutu pelayanan berada pada kategori "B" dan kinerja unit pelayanan "BAIK". Berdasarkan hasil penelitian yang diperoleh dari perhitungan indeks kepuasan masyarakat dapat disimpulkan bahwa pelayanan publik di Kantor Dinas Kependudukan dan Pencatatan Sipil Kota Palangka Raya dapat dikatakan berkualitas baik dan tidak seperti yang dikeluhkan. Hanya penilaian subjektif dari beberapa orang yang mengatakan pelayanan publik masih belum baik, namun perlu untuk ditingkatkan.
\end{abstract}

Kata Kunci : Pelayanan Publik, Indeks Kepuasan Masyarakat

\section{ABSTRACT}

Quality public services are services that are able to meet expectations and exceed the expectations of the people served. Some people complained about public services provided by the Palangka Raya City Population and Civil Registration Office. This study aims to analyze 
the index of public satisfaction with public services at the Office of Population and Civil Registration of the City of Palangka Raya which refers to Kepmenpan No. 25 of 2004 using the theory of SERVQUAL dimensions by Zeithaml et.al (1990) which consists of dimensions of tangible , reliability (reliability), responsiveness (response / responsiveness), assurance (guarantee), and empathy (empathy).

The method used in this study is descriptive quantitative research using the survey method approach. The sampling technique uses non probability sampling techniques with the type of accidental sampling. The number of samples in this study were 100 respondents. The technique of collecting data is done by observation, questionnaire (questionnaire) and documentation.

The results showed that the community satisfaction index value in the Office of Population and Civil Registration of the City of Palangka Raya was 2,963 and the community satisfaction index value after being converted was 74,075 with the service quality being in the " $B$ " category and "GOOD" service unit performance. Based on the results of the research obtained from the calculation of the community satisfaction index, it can be concluded that public services at the Population and Civil Registration Office of Palangka Raya City can be said to be of good quality and not as complained. Only subjective judgments from some people who say public services are still not good, but need to be improved.

Keywords: Public Services, Community Satisfaction Index

\section{PENDAHULUAN}

Masyarakat tidak dapat memenuhi kebutuhannya sendiri sehingga memerlukan bantuan dari orang lain untuk mendapatkan sebuah pelayanan. Pelayanan publik selalu dikaitkan dengan pelayanan yang diberikan oleh pemerintah. Berdasarkan Undang-Undang Nomor 25 Tahun 2009 Bab I Pasal 1, pelayanan publik adalah kegiatan atau rangkaian kegiatan dalam rangka pemenuhan kebutuhan pelayanan sesuai dengan peraturan perundang-undangan bagi setiap warga Negara dan penduduk atas barang, jasa dan/atau pelayanan administratif yang disediakan oleh penyelenggaraan pelayanan publik. Dalam teori ilmu administrasi negara pada hakikatnya pemerintahan negara menyelenggarakan dua jenis fungsi utama, yaitu fungsi pengaturan dan fungsi pelayanan. Fungsi pengaturan dikaitkan dengan hakikat negara sebagai negara hukum (legal state), sedangkan fungsi pelayanan dikaitkan dengan hakikat negara sebagai suatu negara kesejahteraan (welfare state).

Pemerintah sebagai penyelenggara pelayanan publik sudah seharusnya memberikan pelayanan yang berkualitas kepada masyarakat. Masyarakat sebagai penerima pelayanan tentunya menginginkan pelayanan yang berkualitas yang hanya dapat terwujud jika pemerintah memberikan pelayanan yang lebih profesional, efektif, sederhana, transparan, tepat waktu, responsif dan adaptif serta sekaligus dapat membangun kualitas manusia dalam arti meningkatkan kapasitas individu dan masyarakat untuk secara aktif menentukan masa depannya sendiri (Effendi, 2001:12) dalam Hardiyansyah (2011:15).

Salah satu instansi pemerintah yang memberikan pelayanan publik adalah Kantor Dinas Kependudukan dan Pencatatan Sipil Kota Palangka Raya yang terletak di Provinsi Kalimantan Tengah dengan menggunakan pola pelayanan terpadu satu pintu hal ini dikarenakan terdapat beberapa jenis pelayanan dalam satu tempat. Jenis pelayanan yang diberikan berkaitan dengan pelayanan administratif yang terdiri dari 22 jenis pelayanan meliputi pelayanan administrasi kependudukan seperti pelayanan kartu tanda kependudukan elektronik (KTP-E), 
kartu identitas anak (KIA), kartu keluarga (KK) dan sebagainya. Serta pelayanan pencatatan sipil seperti pelayanan akta kelahiran, akta perkawinan, akta kematian dan sebagainya. Dengan adanya beberapa jenis pelayanan yang diberikan tentunya bukanlah hal yang mudah untuk memberikan pelayanan yang maksimal kepada masyarakat. Pelayanan publik sering dikeluhkan oleh masyarakat. Seperti pelayanan publik yang diberikan oleh Kantor Dinas Kependudukan dan Pencatatan Sipil Kota Palangka Raya.

Berdasarkan pengamatan yang telah dilakukan di Kantor Dinas Kependudukan dan Pencatatan Sipil Kota Palangka Raya terdapat beberapa permasalahan yang dikeluhkan oleh masyarakat yaitu terkait dengan waktu penyelesaian proses pelayanan yang memerlukan waktu cukup lama tidak sesuai dengan waktu yang telah ditetapkan, beberapa masyarakat menganggap proses pelayanan masih berbelit-belit, loket pelayanan hanya tersedia beberapa loket saja dengan banyaknya pengunjung mengakibatkan antrian yang cukup panjang, kurangnya fasilitas diruang pelayanan seperti pendingin ruangan juga dikeluhkan oleh masyarakat karena ruangan pelayanan kurang nyaman dengan hawa panas, dan sarana lainnya seperti genset masih belum memadai sehingga apabila listrik padam maka proses pelayanan tidak dapat dilakukan dan terkait jam buka pelayanan dianggap oleh beberapa masyarakat tidak sesuai dengan waktu yang sudah ditentukan.

Berdasarkan latar belakang masalah yang telah dikemukakan tersebut diatas, maka rumusan masalah dalam penelitian ini adalah "Bagaimana indeks kepuasan masyarakat terhadap pelayanan publik di Kantor Dinas Kependudukan dan Pencatatan Sipil Kota Palangka Raya?”. Dan adapun tujuan dalam penelitian ini adalah untuk menganalisis indeks kepuasan masyarakat terhadap pelayanan publik di Kantor Dinas Kependudukan dan Pencatatan Sipil Kota Palangka Raya.

\section{KAJIAN PUSTAKA}

Keputusan Menteri Pendayagunaan Aparatur Negara Nomor 63 Tahun 2003 mendefinisikan pelayanan umum sebagai segala bentuk pelayanan yang dilaksanakan oleh instansi pemerintah di pusat, daerah dan dilingkungan Badan Usaha Milik Negara atau Badan Usaha Milik Daerah dalam bentuk barang dan atau jasa, baik dalam rangka upaya pemenuhan kebutuhan masyarakat maupun dalam rangka pelaksanaan ketentuan peraturan perundang-undangan. Kepmenpan Nomor 63 Tahun 2003 mengelompokkan tiga jenis pelayanan publik yang diselenggarakan oleh pemerintah, sebagai berikut:

a. Pelayanan administratif

b. Pelayanan barang

c. Pelayanan jasa.

Pada dasarnya dalam penyelenggaraan pelayanan publik harus memiliki standar pelayanan yang jelas. Standar pelayanan dilakukan agar pemberi layanan dapat memberikan pelayanan yang sesuai dan memberikan jaminan kepastian bagi penerima pelayanan. Standar pelayanan ini harus ditaati oleh pemberi maupun penerima pelayanan publik. Dalam Kepmenpan Nomor 63 Tahun 2003, standar pelayanan meliputi:

1. Prosedur pelayanan, yaitu prosedur pelayanan yang dibakukan bagi pemberi dan penerima pelayanan termasuk pengaduan yang harus di taati sesuai prosedur yang berlaku oleh pemberi dan penerima pelayanan.

2. Waktu penyelesaian, yaitu pelayanan yang diberikan ditetapkan sejak saat pelayanan diberikan hingga pelayanan terselesaikan. Waktu penyelesaian bagi pemberi dalam memberikan pelayanan kepada penerima sangat mempengaruhi kepuasan penerima pelayanan publik.

3. Biaya pelayanan, yaitu biaya/tarif pelayanan yang ditetapkan dalam proses pemberian pelayanan. Namun 
dalam penetepan besarannya perlu memperhatikan beberapa hal, misalnya tingkat kemampuan dan daya beli masyarakat, rincian biaya yang jelas, nilai/harga yang berlaku atas barang dan jasa, ditetapkan oleh pejabat yang berwenang dengan tetap memperhatikan prosedur dan ketentuan peraturan perundangundangan yang berlaku.

4. Produk pelayanan, yaitu produk yang ditawarkan oleh penyelenggara dan pemberi pelayanan yang sesuai dengan ketentuan yang telah ditetapkan. Sesuai dengan jenis pelayanan nya.

5. Sarana dan prasarana, yaitu adanya penyediaan sarana dan prasarana yang memadai oleh penyelenggara pelayanan publik guna menunjang pelayanan yang diberikan kepada penerima pelayanan.

6. Kompetensi petugas pemberi pelayanan, yaitu dalam memberikan pelayanan perlu adanya petugas yang memiliki kompetensi berdasarkan bidang/keahlian, pengetahuan, keterampilan, sikap dan perilaku. Hal ini sangat mempengaruhi terhadap kepuasan masyarakat sebagai penerima pelayanan. Petugas pemberi pelayanan harus sesuai dengan prosedur yang berlaku.

LAN (2003: 17) menyatakan bahwa kualitas pelayanan sebagai sesuatu yang berhubungan dengan terpenuhinya harapan/kebutuhan pelanggan, dimana pelayanan dikatakan berkualitas apabila dapat menyediakan produk dan jasa (pelayanan) sesuai dengan kebutuhan dan harapan pelanggan. Untuk mengetahui apakah pelayanan yang diberikan berkualitas atau tidak terdapat dimensi kualitas pelayanan (dimensi SERVQUAL) menurut Zeithaml, Parasuraman dan Berry (1990) dalam Hardiyansyah (2011: 46), sebagai berikut:

1. Tangible (Berwujud) terdiri dari beberapa indikator, yaitu :

a. Penampilan petugas/aparatur dalam melayani pelanggan b. Kenyamanan tempat melakukan pelayanan

c. Kemudahan dalam proses pelayanan

d. Kedisiplinan petugas/aparatur dalam melakukan pelayanan

e. Kemudahan akses pelanggan dalam permohonan pelayanan

f. Penggunaan alat bantu dalam pelayanan

2. Reliability (Kehandalan) terdiri dari beberapa indikator, yaitu :

a. Kecermatan petugas dalam melayani pelanggan

b. Memiliki standar pelayanan yang jelas

c. Kemampuan petugas/aparatur dalam menggunakan alat bantu dalam proses pelayanan

d. Keahlian petugas dalam menggunakan alat bantu dalam proses pelayanan

3. Responsiveness (Respon/ Ketanggapan)

a. Merespon setiap pelanggan /pemohon yang ingin mendapatkan pelayanan

b. Petugas/ aparatur melakukan pelayanan dengan cepat

c. Petugas/ aparatur melakukan pelayanan dengan tepat

d. Petugas/ aparatur melakukan pelayanan dengan cermat

e. Petugas/ aparatur melakukan pelayanan dengan waktu yang tepat

f. Semua keluhan pelanggan direspon oleh petugas

4. Assurance (Jaminan)

a. Petugas memberikan jaminan tepat waktu dalam pelayanan

b. Petugas memberikan jaminan biaya dalam pelayanan

c. Petugas memberikan jaminan legalitas dalam pelayanan

d. Petugas memberikan jaminan kepastian biaya dalam pelayanan

5. Empathy (Empati)

a. Mendahulukan kepentingan pemohon/pelanggan

b. Petugas melayani dengan sikap ramah 
c. Petugas melayani dengan sikap sopan santun

d. Petugas melayani dengan tidak diskriminatif (membeda-bedakan)

e. Petugas melayani dan menghargai setiap pelanggan.

Selanjutnya untuk mengukur nilai indeks kepuasan masyarakat menggunakan Keputusan Menteri Pendayagunaan Aparatur Negara Nomor 25 Tahun 2004 Tentang Pedoman Umum Penyusunan Indeks Kepuasan Masyarakat Unit Pelayanan Instansi Pemerintah. Dalam perhitungan IKM terdapat 14 unsur pelayanan yang relevan, valid dan reliabel, sebagai berikut:

1. Prosedur pelayanan, yaitu kemudahan tahapan pelayanan yang diberikan kepada masyarakat dilihat dari sisi kesederhanaan alur pelayanan.

2. Persyaratan pelayanan, yaitu persyaratan teknis dan administratif yang diperlukan untuk mendapatkan pelayanan sesuai dengan jenis pelayanannya.

3. Kejelasan petugas pelayanan, yaitu keberadaan dan kepastian petugas yang memberikan pelayanan (nama, jabatan serta kewenangan dan tanggung jawabnya).

4. Kedisiplinan petugas pelayanan, kesungguhan petugas dalam memberikan pelayanan terutama terhadap konsistensi waktu kerja sesuai ketentuan yang berlaku.

5. Tanggung jawab petugas pelayanan, yaitu kejelasan wewenang dan tanggung jawab petugas dalam penyelenggaraan dan penyelesaian pelayanan.

6. Kemampuan petugas pelayanan, yaitu tingkat keahlian dan ketrampilan yang dimiliki petugas dalam memberikan /menyelesaikan pelayanan kepada masyarakat.

7. Kecepatan pelayanan, yaitu target waktu pelayanan dapat diselesaikan dalam waktu yang telah ditentukan oleh unit penyelenggara pelayanan.
8. Keadilan mendapatkan pelayanan, yaitu pelaksanaan pelayanan dengan tidak membedakan golongan/status masyarakat yang dilayani.

9. Kesopanan dan keramahan petugas, yaitu sikap dan perilaku petugas dalam memberikan pelayanan kepada masyarakat secara sopan dan ramah serta saling menghargai dan menghormati.

10. Kewajaran biaya pelayanan, yaitu keterjangkauan masyarakat terhadap besarnya biaya yang ditetapkan oleh unit pelayanan.

11. Kepastian biaya pelayanan, yaitu kesesuaian antara biaya yang dibayarkan dengan biaya yang telah ditetapkan.

12. Kepastian jadwal pelayanan, yaitu pelaksanaan waktu pelayanan, sesuai dengan ketentuan yang telah ditetapkan.

13. Kenyamanan lingkungan, yaitu kondisi sarana dan prasarana pelayanan yang bersih, rapi dan teratur sehingga dapat memberikan rasa nyaman kepada penerima pelayanan.

14. Keamanan pelayanan, yaitu terjaminnya tingkat keamanan lingkungan unit penyelenggara pelayanan ataupun sarana yang digunakan, sehingga masyarakat merasa tenang untuk mendapatkan pelayanan terhadap resiko-resiko yang diakibatkan dari pelaksanaan pelayanan.

\section{METODE PENELITIAN}

Penelitian ini dilaksanakan di Kantor Dinas Kependudukan dan Pencatatan Sipil Kota Palangka Raya yang beralamat dijalan G.Obos XI/Ir. Soekarno Kota Palangka Raya, Provinsi Kalimantan Tengah. Penelitian menggunakan jenis data kuantitatif deskriptif dengan pendekatan metode survey. Prosedur pemecahan masalah menggunakan penelitian deskriptif ialah dengan menggambarkan kondisi saat sekarang dan fakta-fakta yang ada untuk selanjutnya dapat dianalisis dan 
diinterpretasikan dengan bentuknya berupa survey dan studi perkembangan (Syofian Siregar, 2013:8).

Teknik pengumpulan data dilakukan dengan cara sebagai berikut:

\section{Observasi}

Mengamati secara langsung dilokasi penelitian untuk mengumpulkan data yang dibutuhkan dan mengetahui secara langsung mengenai kegiatan pelayanan yang dilakukan di Kantor Dinas Kependudukan dan Pencatatan Sipil Kota Palangka Raya.

2. Kuesioner

Menyebarkan pertanyaan-pertanyaan beserta dengan jawabannya secara tertulis dan terstruktur. Kuesioner yang digunakan adalah kuesioner tertutup yang memuat pertanyaan sebanyak 21 pertanyaan mengenai tingkat kepuasan masyarakat terhadap pelayanan publik yang diberikan oleh Kantor Dinas Kependudukan dan Pencatatan Sipil Kota Palangka Raya.

3. Dokumentasi

Sebagai data penunjang penelitian berupa foto, dokumen pemerintah maupun undang-undang.

Populasi yang digunakan dalam penelitian ini adalah seluruh masyarakat yang sedang menerima pelayanan publik di Kantor Dinas Kependudukan dan Pencatatan Sipil Kota Palangka Raya. Teknik pengambilan sampel menggunakan teknik non probability sampling dengan jenis accidental sampling dengan jumlah sampel sebanyak 100 orang responden.

Teknik analisis data dilakukan dengan menggunakan analisis Indeks Kepuasan Masyarakat (IKM) berdasarkan KEPMENPAN Nomor 25 Tahun 2004. Dalam perhitungan IKM terdapat 14 unsur pelayanan. Setiap unsur pelayanan memiliki penimbang yang sama dengan rumus sebagai berikut:

$\begin{gathered}\text { Bobot uilai ratavatata } \\ \text { tertimbang }\end{gathered}=\frac{\text { Jumlah Bobot }}{\text { Jumlah Unsul' }}=\frac{1}{14}=0,071$

Selanjutnya untuk memperoleh nilai IKM digunakan rumus sebagai berikut:

$$
\text { IKM }=\frac{\text { Total Dari Nilai Persepsi Per Unsur }}{\text { Total Unsur Yang Terisi }} \times \quad \text { Nillai Penimbang }
$$

Untuk memudahkan interpretasi terhadap penilaian IKM yaitu antara 25 100 maka hasil penelitian tersebut diatas dikonversikan dengan nilai dasar 25, dengan rumus sebagai berikut:

IKM Unit Pelayanan $\quad x \quad 25$

Mengingat unit pelayanan mempunyai karakteristik yang berbedabeda, maka setiap unit pelayanan dimungkinkan untuk :

a. Menambah unsur yang dianggap relevan.

b. Memberikan bobot yang berbeda terhadap 14 (empat belas) unsur yang dominan dalam unit pelayanan, dengan catatan jumlah bobot seluruh unsur tetap 1.

Tabel 6. Nilai Persepsi, Interval IKM, Interval Konversi IKM, Mutu Pelayanan dan Kinerja Unit Pelayanan

\begin{tabular}{|c|c|c|c|c|}
\hline $\begin{array}{c}\text { Nilai } \\
\text { Persepsi }\end{array}$ & $\begin{array}{c}\text { Nilai } \\
\text { Interval } \\
\text { IKM }\end{array}$ & $\begin{array}{c}\text { Nilai Interval } \\
\text { Konversi IKM }\end{array}$ & $\begin{array}{c}\text { Mutu } \\
\text { Pelayanan }\end{array}$ & $\begin{array}{c}\text { Kinerja } \\
\text { Unit } \\
\text { Pelayanan }\end{array}$ \\
\hline 1 & $1,00-1,75$ & $25-43,75$ & D & Tidak Baik \\
\hline 2 & $1,76-2,50$ & $43,76-62,50$ & C & Kurang Baik \\
\hline 3 & $2,51-3,25$ & $62,51-81,25$ & B & Baik \\
\hline 4 & $3,26-4,00$ & $81,26-100,00$ & A & Sangat Baik \\
\hline
\end{tabular}

\section{HASIL PENELITIAN}

Identitas responden yang dianalisis terdiri dari jenis kelamin, umur, pendidikan terakhir, pekerjaan utama, dan pelayanan yang diberikan sebagai berikut:

1. Identitas Responden Berdasarkan Jenis Kelamin 


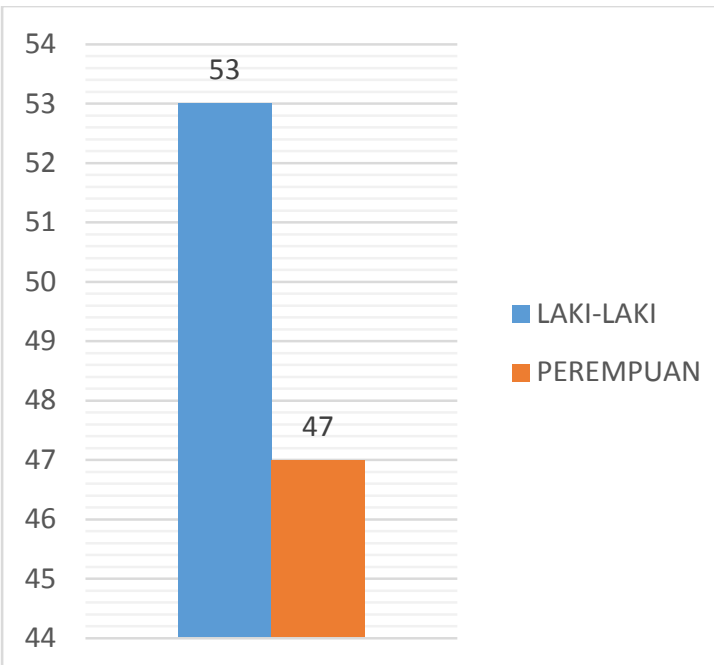

Berdasarkan diagram tersebut, jumlah responden adalah sebanyak 100 orang yang terdiri dari 53 orang laki-laki dan 47 orang perempuan. Dengan demikian dapat diketahui bahwa masyarakat yang menerima pelayanan di Kantor Dinas Kependudukan dan Pencatatan Sipil Kota Palangka Raya lebih banyak berjenis kelamin laki-laki dengan jumlah sebanyak 53 orang dengan persentase $53 \%$.

2. Identitas Responden Berdasarkan Umur

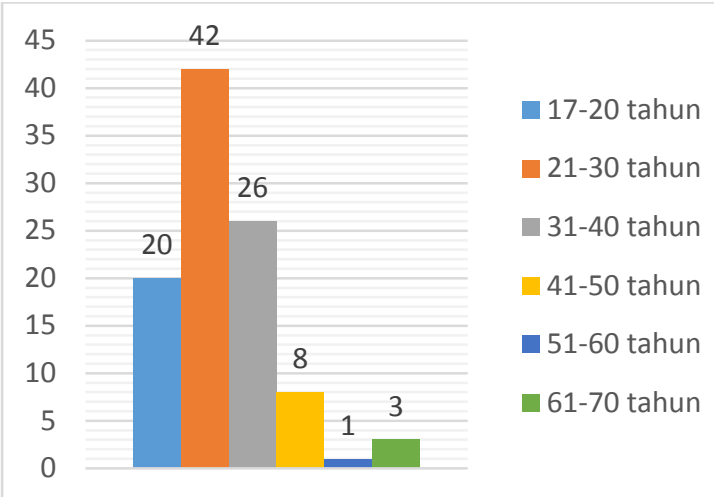

Berdasarkan diagram tersebut, identitas responden berdasarkan umur antara 17-20 tahun sebanyak 20 orang, 2130 tahun sebanyak 42 orang, 31-40 tahun sebanyak 26 orang, 41-50 sebanyak 8 orang, 51-60 tahun sebanyak 1 orang dan 61-70 tahun sebanyak 3 orang. Dengan demikian dapat diketahui bahwa dari 100 orang yang menerima pelayanan publik di Kantor Dinas Kependudukan dan Pencatatan Sipil Kota Palangka Raya berdasarkan umurnya paling banyak berusia antara 21-30 tahun dengan jumlah sebanyak 42 orang dengan persentase $42 \%$

3. Identitas Responden Berdasarkan Pendidikan Terakhir

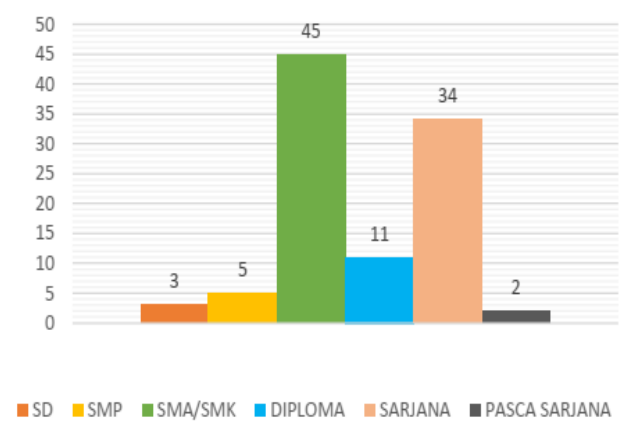

Berdasarkan diagram tersebut, dari 100 orang responden memiliki pendidikan terakhir, yaitu SD sebanyak 3 orang, SMP sebanyak 5 orang, SMA/SMK sebanyak 45 orang, Diploma sebanyak 11 orang, Sarjana sebanyak 34 orang, dan Pasca Sarjana sebanyak 2 orang. Dengan demikian dapat diketahui bahwa dari 100 orang yang menerima pelayanan publik di Kantor Dinas Kependudukan dan Pencatatan Sipil Kota Palangka Raya berdasarkan pendidikan terakhir paling banyak adalah SMA/SMK dengan jumlah sebanyak 45 orang dengan persentase $45 \%$.

4. Identitas Responden Berdasarkan Pekerjaan Utama

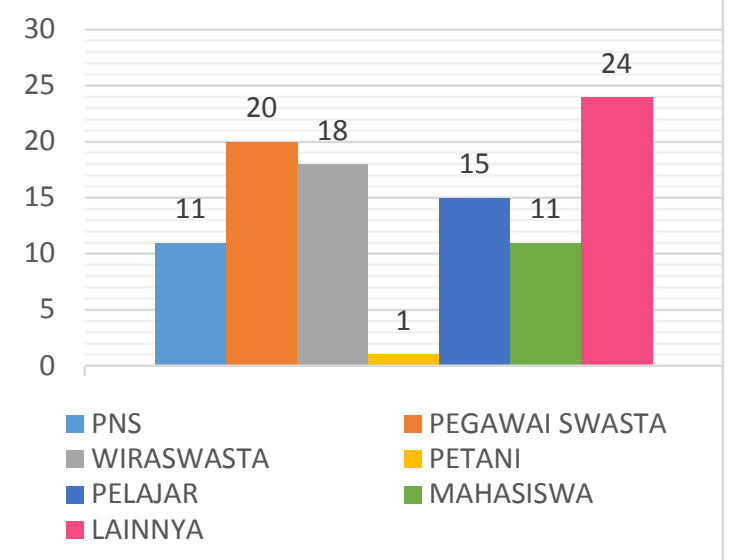

Berdasarkan diagram tersebut, dari 100 orang responden memiliki pekerjaan utamanya, yaitu PNS sebanyak 11 orang, Pegawai Swasta sebanyak 20 orang, Wiraswasta sebanyak 18 orang, Petani sebanyak 1 orang, Pelajar sebanyak 15 orang, Mahasiswa sebanyak 11 orang dan 
lainnya sebanyak 24 orang. Dengan demikian dapat diketahui bahwa dari 100 orang yang menerima pelayanan publik di Kantor Dinas Kependudukan dan Pencatatan Sipil Kota Palangka Raya berdasarkan pekerjaan utamanya paling banyak adalah lainnya dengan jumlah sebanyak 24 orang dengan persentase $24 \%$.

5. Identitas Responden Berdasarkan Pelayanan Yang Diberikan

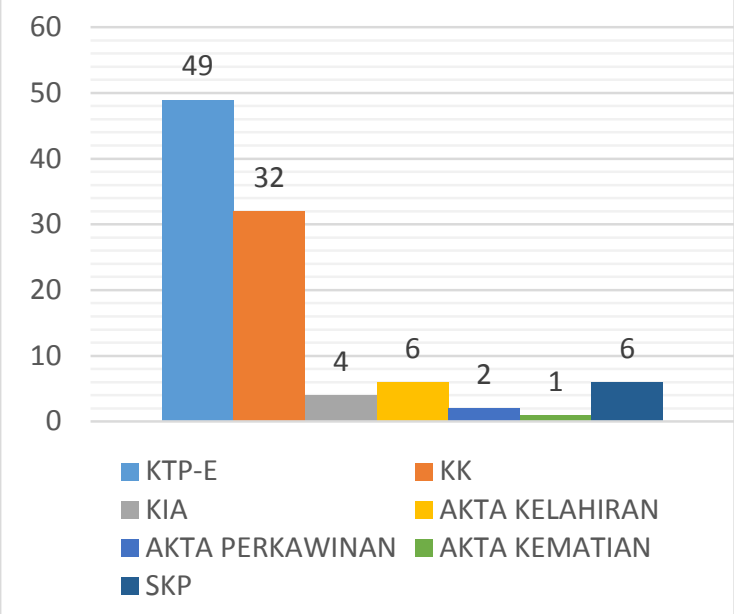

Berdasarkan diagram tersebut, dari 100 orang responden berdasarkan pelayanan yang diberikan terdapat 7 pelayanan yang sering diberikan, yaitu Pelayanan Kartu Tanda Kependudukan Elektronik (KTP-E) sebanyak 49 orang, Kartu Keluarga (KK) sebanyak 32 orang, Kartu Identitas Anak (KIA) sebanyak 4 orang, Akta Kelahiran sebanyak 6 orang, Akta Perkawinan sebanyak 2 orang, Akta Kematian sebanyak 1 orang dan Surat Keterangan Pindah (SKP) sebanyak 6 orang. Dengan demikian dapat diketahui bahwa dari 100 orang yang menerima pelayanan publik di Kantor Dinas Kependudukan dan Pencatatan Sipil Kota Palangka Raya berdasarkan pelayanan yang diberikan paling banyak adalah Pelayanan E-KTP dengan jumlah sebanyak 49 orang dengan persentase $49 \%$.

\section{Uji Validitas}

Dalam penelitian ini teknik pengukuran menggunakan kuesioner dengan jumlah pertanyaan sebanyak 22 pertanyaan untuk mengukur indeks kepuasan masyarakat dan dilakukan uji validitas instrumen penelitian menggunakan SPSS 25 for Windows dengan $\mathrm{N}=30$ sangat disarankan agar jumlah responden untuk uji coba minimal 30 orang menurut Masri Singarimbun dan Sofian Effendi (2015:137) dan taraf signifikan 5\% adalah 0,361 sesuai dengan nilai $\mathrm{r}$ product moment dalam Sugiyono (2016:369). Berikut tabel hasil analisis tiaptiap item instrumen penelitian.

Tabel 1. Hasil Analisis Item Instrumen

\begin{tabular}{|c|c|c|}
\hline $\begin{array}{c}\text { No. Butir } \\
\text { Instrumen }\end{array}$ & $\begin{array}{c}\text { Koefisien } \\
\text { Korelasi }\end{array}$ & Keterangan \\
\hline 1 & 0,752 & Valid \\
\hline 2 & 0,674 & Valid \\
\hline 3 & 0,822 & Valid \\
\hline 4 & 0,724 & Valid \\
\hline 5 & 0,710 & Valid \\
\hline 6 & 0,676 & Valid \\
\hline 7 & 0,707 & Valid \\
\hline 8 & 0,732 & Valid \\
\hline 9 & 0,794 & Valid \\
\hline 10 & 0,622 & Valid \\
\hline 11 & 0,674 & Valid \\
\hline 12 & 0,787 & Valid \\
\hline 13 & 0,497 & Valid \\
\hline 14 & 0,648 & Valid \\
\hline 15 & 0,272 & Tidak Valid \\
\hline 16 & 0,738 & Valid \\
\hline 17 & 0,619 & Valid \\
\hline 18 & 0,651 & Valid \\
\hline 19 & 0,778 & Valid \\
\hline 20 & 0,529 & Valid \\
\hline 21 & 0,530 & Valid \\
\hline 22 & 0,715 & Valid \\
\hline Ber
\end{tabular}

Berdasarkan tabel diatas dapat dinyatakan bahwa terdapat 1 butir instrumen yang tidak valid, yaitu dalam indikator keadilan mendapatkan pelayanan pada butir instrumen nomor 15 yaitu petugas melayani dan menghargai masyarakat yang dilayani, hal ini dikarenakan pertanyaan sudah terjawab pada butir instrumen nomor 13 yaitu petugas dalam memberikan pelayanan tidak diskriminatif (membeda-bedakan) yang berarti petugas dalam memberikan pelayanan harus menghargai masyarakat yang dilayani tanpa membeda-bedakan status, ras maupun golongan. Sedangkan butir instrumen lainnya dinyatakan valid 
dan dapat digunakan untuk menganalisis indeks kepuasan masyarakat terhadap pelayanan publik di Kantor Dinas Kependudukan dan Pencatatan Sipil Kota Palangka Raya.

\section{Uji Reliabilitas}

Perhitungan reliabilitas yang peneliti gunakan adalah menggunakan koefisien Alpha Cronbach. Hasil perhitungan yang diperoleh kemudian diinterpretasikan dengan tabel pedoman untuk memberikan interpretasi terhadap koefisien korelasi seperti tabel berikut:

Tabel 2. Interpretasi Koefisien Korelasi

\begin{tabular}{|c|c|}
\hline Interval Koefisien & Tingkat Hubungan \\
\hline $0,00-0,199$ & Sangat Rendah \\
\hline $0,20-0,399$ & Rendah \\
\hline $0,40-0,599$ & Sedang \\
\hline $0,60-0,799$ & Kuat \\
\hline $0,80-1,000$ & Sangat Kuat \\
\hline
\end{tabular}

(Sugiyono, 2016: 214)

Dalam penelitian ini menggunakan SPSS 25 for Windows. Berikut hasil uji coba reliabilitas penelitian.

Tabel 3. Hasil Uji Coba Reliabilitas Penelitian

\begin{tabular}{l|c|c|}
\hline Variebel & $\begin{array}{c}\text { Koefisien } \\
\text { Cronbach's } \\
\text { Alpha }\end{array}$ & $\begin{array}{c}\text { Keterangan } \\
\text { Reliabilitas }\end{array}$ \\
\hline $\begin{array}{l}\text { Indeks } \\
\text { Kepuasan } \\
\text { Masyarakat }\end{array}$ & 0,939 & Sangat Kuat \\
\hline $\begin{array}{l}\text { Sehingga instrumen penelitian ini } \\
\text { dinyatakan reliabel dikarenakan nilai } \\
\text { koefisien Alpha Cronbach lebih besar dari } \\
\text { 0,361. }\end{array}$
\end{tabular}

\section{Hasil Analisis Indeks Kepuasan Masyarakat (IKM)}

Berdasarkan hasil perhitungan Indeks Kepuasan Masyarakat (IKM), jumlah nilai dari setiap unit pelayanan diperoleh dari jumlah nilai rata-rata setiap unsur pelayanan, sehingga diperoleh hasil sebagai berikut:

Tabel 4. Hasil Pengolahan IKM Per Unsur Pelayanan

\begin{tabular}{|c|c|c|}
\hline No & Unsur Pelayanan & $\begin{array}{c}\text { Nilai Unsur } \\
\text { Pelayanan }\end{array}$ \\
\hline 1 & Prosedur Pelayanan & 3,01 \\
\hline
\end{tabular}

\begin{tabular}{|c|l|c|}
2 & Persyaratan Pelayanan & 3,14 \\
\hline 3 & $\begin{array}{l}\text { Kejelasan Petugas } \\
\text { Pelayanan }\end{array}$ & 2,98 \\
\hline 4 & $\begin{array}{l}\text { Kedisiplinan Petugas } \\
\text { Pelayanan }\end{array}$ & 2,89 \\
\hline 5 & $\begin{array}{l}\text { Tanggung Jawab } \\
\text { Petugas Pelayanan }\end{array}$ & 3,03 \\
\hline 6 & $\begin{array}{l}\text { Kemampuan Petugas } \\
\text { Pelayanan }\end{array}$ & 2,70 \\
\hline 7 & Kecepatan Pelayanan \\
\hline 8 & $\begin{array}{l}\text { Keadilan Mendapatkan } \\
\text { Pelayanan }\end{array}$ & 3,98 \\
\hline 9 & $\begin{array}{l}\text { Kesopanan dan } \\
\text { Keramahan Petugas }\end{array}$ \\
\hline 10 & $\begin{array}{l}\text { Kewajaran Biaya } \\
\text { Pelayanan }\end{array}$ & 3,15 \\
\hline 11 & $\begin{array}{l}\text { Kepastian Biaya } \\
\text { Pelayanan }\end{array}$ & $\begin{array}{l}\text { Kepastian Jadwal } \\
\text { Pelayanan }\end{array}$ \\
\hline 13 & $\begin{array}{l}\text { Kenyamanan } \\
\text { Lingkungan }\end{array}$ & 2,86 \\
\hline 14 & Keamanan Pelayanan & 2,91 \\
\hline & $\begin{array}{l}\text { Untuk mengetahui nilai indeks unit } \\
\text { inta }\end{array}$ \\
\hline
\end{tabular}
pelayanan di Kantor Dinas Kependudukan dan Pencatatan Sipil Kota Palangka Raya dihitung dengan cara sebagai berikut:

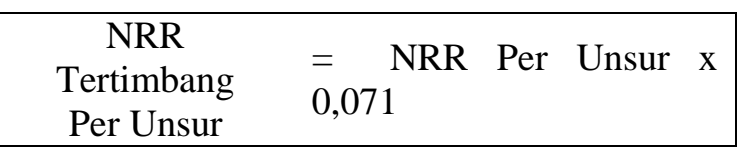

$(3,01 \times 0,071)+(3,14 \times 0,071)+(2,98 \times$ $0,071)+(2,89 \times 0,071)+(3,03 \times 0,071)+(3,05$ $\times 0,071)+(2,70 \times 0,071)+(2,98 \times 0,071)+$ $(3,07 \times 0,071)+(3,15 \times 0,071)+(3,14 \times 0,071)$ $+(2,86 \times 0,071)+$ $(2,83 \times 0,071)+(2,91 \times 0,071)=2,963$

Jadi, nilai indeksnya adalah 2,963.

Selanjutnya untuk memudahkan interpretasi terhadap penilaian IKM yaitu antara 25-100, maka hasil penilaian tersebut diatas dikonversikan dengan nilai dasar 25, dengan rumus sebagai berikut:

Nilai Konversi IKM = Nilai Indeks x 25

Nilai konversi IKM = 2,963 x 25 = 74,075

Tabel 5. Perolehan Nilai Konversi IKM Masing-Masing Unsur Pelayanan 


\begin{tabular}{|c|c|c|c|c|}
\hline No & $\begin{array}{c}\text { Unsur } \\
\text { Pelayanan }\end{array}$ & $\begin{array}{l}\text { Nilai } \\
\text { Konversi } \\
\text { IKM }\end{array}$ & Mutu & Kinerja \\
\hline 1 & $\begin{array}{l}\text { Prosedur } \\
\text { Pelayanan }\end{array}$ & 75,25 & B & Baik \\
\hline 2 & $\begin{array}{l}\text { Persyaratan } \\
\text { Pelayanan }\end{array}$ & 78,50 & B & Baik \\
\hline 3 & $\begin{array}{l}\text { Kejelasan } \\
\text { Petugas } \\
\text { Pelayanan } \\
\end{array}$ & 74,50 & B & Baik \\
\hline 4 & $\begin{array}{l}\text { Kedisiplinan } \\
\text { Petugas } \\
\text { Pelayanan }\end{array}$ & 72,25 & B & Baik \\
\hline 5 & $\begin{array}{l}\text { Tanggung } \\
\text { Jawab Petugas } \\
\text { Pelayanan }\end{array}$ & 75,75 & B & Baik \\
\hline 6 & $\begin{array}{l}\text { Kemampuan } \\
\text { Petugas } \\
\text { Pelayanan }\end{array}$ & 76,25 & B & Baik \\
\hline 7 & $\begin{array}{l}\text { Kecepatan } \\
\text { Pelayanan }\end{array}$ & 67,50 & B & Baik \\
\hline 8 & $\begin{array}{l}\text { Keadilan } \\
\text { Mendapatkan } \\
\text { Pelayanan }\end{array}$ & 74,50 & B & Baik \\
\hline 9 & $\begin{array}{l}\text { Kesopanan dan } \\
\text { Keramahan } \\
\text { Petugas }\end{array}$ & 76,75 & B & Baik \\
\hline 10 & $\begin{array}{l}\text { Kewajaran } \\
\text { Biaya } \\
\text { Pelayanan }\end{array}$ & 78,75 & B & Baik \\
\hline 11 & $\begin{array}{l}\text { Kepastian } \\
\text { Biaya } \\
\text { Pelayanan }\end{array}$ & 78,50 & B & Baik \\
\hline 12 & $\begin{array}{l}\text { Kepastian } \\
\text { Jadwal } \\
\text { Pelayanan }\end{array}$ & 71,50 & B & Baik \\
\hline 13 & $\begin{array}{l}\text { Kenyamanan } \\
\text { Lingkungan }\end{array}$ & 70,75 & B & Baik \\
\hline 14 & $\begin{array}{l}\text { Keamanan } \\
\text { Pelayanan }\end{array}$ & 72,75 & B & Baik \\
\hline
\end{tabular}

Nilai konversi IKM dari masingmasing unsur pelayanan tersebut menunjukkan penilaian masyarakat terhadap 14 unsur pelayanan publik sehingga nilai interval konversi IKM di Kantor Dinas Kependudukan dan Pencatatan Sipil Kota Palangka Raya adalah sebesar $\mathbf{7 4 . 0 7 5}$ dengan mutu pelayanan berada pada kategori “B” dan kinerja unit pelayanan berada pada kategori "BAIK".

\section{PEMBAHASAN}

Untuk dapat mewujudkan pelayanan publik yang berkualitas dan mampu menghasilkan kepuasan masyarakat tentu perlu dilakukan upaya-upaya peningkatan terhadap kualitas pelayanan publik yang diberikan. Pelayanan publik yang berkualitas dapat dilihat dari beberapa dimensi menurut Zeithaml et.al. (1990) sebagai berikut:

Tangible (berwujud), yaitu penyediaan fasilitas fisik dan kelengkapan serta penampilan petugas. Dalam hal ini penyediaan fasilitas fisik seperti sarana sangat mempengaruhi kualitas pelayanan publik yang diberikan kepada masyarakat. Adanya sarana pelayanan yang memadai sangatlah penting dan berpengaruh dalam pelayanan publik. Berdasarkan hasil penelitian yang telah dilakukan pada Kantor Disdukcapil Kota Palangka Raya masih terdapat beberapa kekurangan yang berkaitan dengan sarana pelayanan, yaitu fasilitas seperti genset kurang dioptimalkan sehingga ketika listrik padam maka proses pelayanan tidak dapat dilakukan. Dan juga fasilitas lainnya seperti pendingin ruangan masih belum dioptimalkan sehingga mengakibatkan kondisi ruang pelayanan yang kurang nyaman dengan hawa panas. Selanjutnya berkaitan dengan penampilan petugas yang memberikan pelayanan sudah baik dengan berpenampilan bersih dan rapi. Dengan demikian, maka perlu ditingkatkan dan diperbaiki lagi terkait dengan sarana pelayanan agar terwujudnya kualitas pelayanan.

Reliability (kehandalan), yaitu kemampuan memproduksi jasa sesuai yang diinginkan secara tepat. Hal ini berkaitan dengan kemampuan Kantor Disdukcapil Kota Palangka Raya dalam memberikan pelayanan kepada masyarakat sebagaimana yang telah dijanjikan secara cepat, tepat dan cermat. Dari hasil penelitian yang telah dilakukan, beberapa masyarakat yang mendapatkan pelayanan merasakan bahwa pelayanan yang diberikan masih belum sesuai harapan terkait dengan kecepatan pelayanan. Dalam hal ini petugas pelayanan dalam memberikan pelayanan masih 
memerlukan waktu yang cukup lama tidak sesuai dengan ketentuan yang berlaku. Pelayanan di Kantor Disdukcapil Kota Palangka Raya bergantung pada sistem pelayanan, sehingga ketika sistem sedang bermasalah maka pelayanan tidak dapat dilakukan dan tentunya menghambat proses pelayanan. Dengan demikian, maka perlu ditingkatkan dan diperbaiki lagi berkaitan dengan kecepatan pelayanan yang diberikan kepada masyarakat.

\section{Responsiveness}

(respon /

ketanggapan), yaitu kemampuan untuk membantu pelanggan dalam memberikan pelayanan yang tepat. Daya tanggap dalam hal ini berkaitan dengan kemampuan petugas dalam memberikan informasi kepada masyarakat dan ketanggapan petugas pelayanan dalam menanggapi setiap keluhan masyarakat terhadap pelayanan yang diberikan. Dari hasil penelitian yang telah dilakukan, petugas pelayanan sudah baik dalam menanggapi setiap keluhan masyarakat. Namun beberapa masyarakat beranggapan bahwa petugas pelayanan masih kurang baik dalam menanggapi keluhan terkait pelayanan yang diberikan.

Assurance (jaminan), yaitu pengetahuan dan kemampuan petugas untuk meyakinkan pelanggan. Kantor Disdukcapil Kota Palangka Raya setiap harinya ramai dikunjungi oleh masyarakat yang ingin mendapatkan pelayanan. Dengan ramainya jumlah pengunjung tersebut, maka sudah seharusnya masyarakat mendapatkan kenyamanan selama pelayanan dengan memberikan rasa aman bagi masyarakat yang dilayani baik dilingkungan luar kantor maupun dilingkungan dalam kantor. Dari hasil penelitian, keamanan pelayanan di Kantor Disdukcapil Kota Palangka Raya sudah baik, namun perlu ditingkatkan dan diperbaiki lagi berkaitan dengan kenyamanan selama berada diruang pelayanan dan keamanan dilingkungan kantor seperti tempat parkir yang masih belum ada petugas yang menjaga kendaraan. Namun meskipun demikian, belum pernah terjadi permasalahan yang berkaitan dengan keamanan pelayanan di Kantor Disdukcapil Kota Palangka Raya.

Empathy (empati), yaitu tingkat perhatian dan atensi individual yang diberikan kepada pelanggan. Petugas pelayanan dalam memberikan pelayanan tentunya memberikan perhatian/rasa peduli terhadap masyarakat yang dilayani. Sehingga diperlukan komunikasi yang baik antara petugas pelayanan dan masyarakat yang dilayani. Dari hasil penelitian yang telah dilakukan, masyarakat menganggap bahwa petugas pelayanan sudah baik selama memberikan pelayanan, petugas menghargai dan bersikap sopan santun kepada masyarakat. Namun, beberapa masyarakat masih beranggapan bahwa petugas pelayanan masih kurang baik. Sehingga perlu ditingkatkan dan diperbaiki lagi.

Selanjutnya berdasarkan data penelitian diatas, maka akan dibahas mengenai masing-masing unsur pelayanan menurut Kepmenpan Nomor 25 Tahun 2004 yang terdiri dari 14 unsur pelayanan yang digunakan sebagai alat pengukuran Indeks Kepuasan Masyarakat di Kantor Dinas Kependudukan dan Pencatatan Sipil Kota Palangka, yaitu :

\section{Prosedur Pelayanan}

Nilai IKM untuk prosedur pelayanan di Kantor Disdukcapil Kota Palangka Raya adalah sebesar 3,01 dengan nilai konversi IKM sebesar 75,25. Maka berdasarkan hasil penelitian tersebut, prosedur pelayanan di Kantor Disdukcapil Kota Palangka Raya memiliki mutu pelayanan berada pada kategori "B" dan kinerja unit pelayanan "BAIK". Akan tetapi meskipun demikian masih ada beberapa masyarakat yang menganggap bahwa prosedur pelayanan di Kantor Disdukcapil Kota Palangka Raya sulit dipahami, berbelit-belit dan belum jelas. Berdasarkan hal tersebut, maka perlu adanya upaya untuk meningkatkan kejelasan prosedur pelayanan kepada masyarakat. 


\section{Persyaratan Pelayanan}

Nilai IKM untuk persyaratan pelayanan di Kantor Disdukcapil Kota Palangka Raya adalah sebesar 3,14 dengan nilai konversi IKM sebesar 78,50. Maka berdasarkan hasil penelitian tersebut, persyaratan pelayanan di Kantor Disdukcapil Kota Palangka Raya memiliki mutu pelayanan berada pada kategori "B" dan kinerja unit pelayanan "BAIK”. Akan tetapi meskipun demikian masih ada beberapa masyarakat yang menganggap bahwa persyaratan pelayanan di Kantor Disdukcapil Kota Palangka Raya masih belum sesuai dengan pelayanan yang diajukan. Berdasarkan hal tersebut, maka perlu adanya upaya untuk meningkatkan kejelasan dan kemudahan persyaratan pelayanan kepada masyarakat.

\section{Kejelasan Petugas Pelayanan}

Nilai IKM untuk kejelasan petugas pelayanan di Kantor Disdukcapil Kota Palangka Raya adalah sebesar 2,98 dengan nilai konversi IKM sebesar 74,50. Maka berdasarkan hasil penelitian tersebut, kejelasan petugas pelayanan di Kantor Disdukcapil Kota Palangka Raya memiliki mutu pelayanan berada pada kategori "B" dan kinerja unit pelayanan "BAIK". Akan tetapi meskipun demikian masih ada beberapa masyarakat yang menganggap bahwa petugas dalam memberikan informasi sulit dipahami dan keberadaan petugas pada saat jam pelayanan tidak jelas hal ini banyak dikeluhkan oleh masyarakat. Berdasarkan hal tersebut, maka perlu adanya upaya untuk meningkatkan kejelasan petugas pelayanan demi terwujudnya tingkat kepuasan masyarakat dan pelayanan yang berkualitas.

\section{Kedisiplinan Petugas Pelayanan}

Nilai IKM untuk kedisiplinan petugas pelayanan di Kantor Disdukcapil Kota Palangka Raya adalah sebesar 2,89 dengan nilai konversi IKM sebesar 72,25. Maka berdasarkan hasil penelitian tersebut, kedisiplinan petugas pelayanan di Kantor Disdukcapil Kota Palangka Raya memiliki mutu pelayanan berada pada kategori "B" dan kinerja unit pelayanan "BAIK". Akan tetapi meskipun demikian masih ada beberapa masyarakat yang menganggap bahwa kedisiplinan petugas pelayanan di Kantor Disdukcapil Kota Palangka Raya masih belum sesuai hal ini dikarenakan petugas dalam memberikan pelayanan tidak konsisten terhadap waktu yang telah ditetapkan. Berdasarkan hal tersebut, maka perlu adanya upaya untuk meningkatkan kedisiplinan petugas pelayanan.

\section{Tanggung Jawab Petugas Pelayanan}

Nilai IKM untuk tanggung jawab petugas pelayanan di Kantor Disdukcapil Kota Palangka Raya adalah sebesar 3,03 dengan nilai konversi IKM sebesar 75,75. Maka berdasarkan hasil penelitian tersebut, tanggung jawab petugas pelayanan di Kantor Disdukcapil Kota Palangka Raya memiliki mutu pelayanan berada pada kategori "B" dan kinerja unit pelayanan "BAIK". Akan tetapi meskipun demikian masih ada beberapa masyarakat yang menganggap bahwa tanggung jawab petugas dalam memberikan pelayanan masih kurang sesuai hal ini dikarenakan keluhan masyarakat terkait pelayanan yang diberikan tidak mendapatkan kejelasan. Berdasarkan hal tersebut, maka perlu adanya upaya untuk meningkatkan tanggung jawab petugas pelayanan demi terwujudnya tingkat kepuasan masyarakat dan pelayanan yang berkualitas.

\section{Kemampuan Petugas Pelayanan}

Nilai IKM untuk kemampuan petugas pelayanan di Kantor Disdukcapil Kota Palangka Raya adalah sebesar 3,05 dengan nilai konversi IKM sebesar 76,25. Maka berdasarkan hasil penelitian tersebut, kemampuan petugas pelayanan di Kantor Disdukcapil Kota Palangka Raya memiliki mutu pelayanan berada pada kategori "B" dan kinerja unit pelayanan "BAIK". Akan tetapi meskipun demikian masih ada beberapa masyarakat yang menganggap bahwa kemampuan petugas dalam memberikan pelayanan masih kurang. 
Berdasarkan hal tersebut, maka perlu adanya upaya untuk meningkatkan kemampuan petugas dalam memberikan pelayanan kepada masyarakat.

\section{Kecepatan Pelayanan}

Nilai IKM untuk kecepatan pelayanan di Kantor Disdukcapil Kota Palangka Raya adalah sebesar 2,70 dengan nilai konversi IKM sebesar 67,50. Maka berdasarkan hasil penelitian tersebut, kecepatan pelayanan di Kantor Disdukcapil Kota Palangka Raya memiliki mutu pelayanan berada pada kategori "B" dan kinerja unit pelayanan "BAIK". Akan tetapi meskipun demikian masih ada beberapa masyarakat yang menganggap bahwa kecepatan pelayanan di Kantor Disdukcapil Kota Palangka Raya masih kurang hal ini dikarenakan sistem pelayanan terkadang bermasalah sehingga petugas dalam memberikan pelayanan memerlukan waktu yang cukup lama tidak sesuai dengan waktu yang telah ditentukan. Berdasarkan hal tersebut, perlu adanya upaya untuk meningkatkan kecepatan pelayanan yang diberikan kepada masyarakat.

\section{Keadilan Mendapatkan Pelayanan}

Nilai IKM untuk kemampuan petugas pelayanan di Kantor Disdukcapil Kota Palangka Raya adalah sebesar 2,98 dengan nilai konversi IKM sebesar 74.50. Maka berdasarkan hasil penelitian tersebut, keadilan medapatkan pelayanan di Kantor Disdukcapil Kota Palangka Raya memiliki mutu pelayanan berada pada kategori "B" dan kinerja unit pelayanan "BAIK". Akan tetapi meskipun demikian masih ada beberapa masyarakat yang menganggap bahwa keadilan mendapatkan pelayanan masih kurang baik. Berdasarkan hal tersebut, maka perlu adanya upaya untuk meningkatkan keadilan dalam memberikan pelayanan kepada masyarakat

\section{Kesopanan dan Keramahan Petugas}

Nilai IKM untuk kesopanan dan keramahan petugas di Kantor Disdukcapil Kota Palangka Raya adalah sebesar 3,07 dengan nilai konversi IKM sebesar 76,75. Maka berdasarkan hasil penelitian tersebut, kesopanan dan keramahan petugas di Kantor Disdukcapil Kota Palangka Raya memiliki mutu pelayanan berada pada kategori "B" dan kinerja unit pelayanan "BAIK". Akan tetapi meskipun demikian masih ada beberapa masyarakat yang menganggap bahwa kesopanan dan keramahan petugas di Kantor Disdukcapil Kota Palangka Raya masih kurang. Berdasarkan hal tersebut, maka perlu adanya upaya untuk meningkatkan sikap yang dimiliki oleh petugas pelayanan.

\section{Kewajaran Biaya Pelayanan}

Nilai IKM untuk kewajaran biaya pelayanan di Kantor Disdukcapil Kota Palangka Raya adalah sebesar 3,15 dengan nilai konversi IKM sebesar 78,75. Maka berdasarkan hasil penelitian tersebut, kewajaran biaya pelayanan di Kantor Disdukcapil Kota Palangka Raya memiliki mutu pelayanan berada pada kategori "B" dan kinerja unit pelayanan "BAIK". Akan tetapi meskipun demikian masih ada beberapa masyarakat yang menganggap bahwa kewajaran biaya pelayanan yang dibayarkan belum sesuai dengan yang telah ditetapkan. Berdasarkan hal tersebut, maka perlu adanya upaya untuk meningkatkan kejelasan terkait dengan biaya yang harus dibayarkan berdasarkan ketentuan yang berlaku.

\section{Kepastian Biaya Pelayanan}

Nilai IKM untuk kepastian biaya pelayanan di Kantor Disdukcapil Kota Palangka Raya adalah sebesar 3,14 dengan nilai konversi IKM sebesar 78,50. Maka berdasarkan hasil penelitian tersebut, kepastian biaya pelayanan di Kantor Disdukcapil Kota Palangka Raya memiliki mutu pelayanan berada pada kategori "B" dan kinerja unit pelayanan "BAIK". Akan tetapi meskipun demikian masih ada beberapa masyarakat yang menganggap bahwa masih ada pungutan biaya tambahan yang dibayarkan tidak sesuai dengan biaya yang telah ditetapkan. Berdasarkan hal 
tersebut, maka perlu adanya upaya untuk meningkatkan pelayanan yang diberikan terkait dengan biaya yang harus dibayarkan harus jelas.

\section{Kepastian Jadwal Pelayanan}

Nilai IKM untuk kepastian jadwal pelayanan di Kantor Disdukcapil Kota Palangka Raya adalah sebesar 2,86 dengan nilai konversi IKM sebesar 71,50. Maka berdasarkan hasil penelitian tersebut, kepastian jadwal pelayanan di Kantor Disdukcapil Kota Palangka Raya memiliki mutu pelayanan berada pada kategori "B" dan kinerja unit pelayanan "BAIK". Akan tetapi meskipun demikian masih ada beberapa masyarakat yang menganggap bahwa pelayanan yang diberikan masih kurang baik, hal ini dikarenakan jadwal pelayanan yang tidak sesuai dengan ketentuan yang berlaku. Berdasarkan hal tersebut, maka perlu adanya upaya untuk meningkatkan kepastian jadwal pelayanan yang diberikan.

\section{Kenyamanan Lingkungan}

Nilai IKM untuk kepastian jadwal pelayanan di Kantor Disdukcapil Kota Palangka Raya adalah sebesar 2,83 dengan nilai konversi IKM sebesar 70,75. Maka berdasarkan hasil penelitian tersebut, kenyamanan lingkungan di Kantor Disdukcapil Kota Palangka Raya memiliki mutu pelayanan berada pada kategori "B" dan kinerja unit pelayanan "BAIK". Akan tetapi meskipun demikian masih ada beberapa masyarakat yang menganggap bahwa tempat melakukan pelayanan masih kurang nyaman, hal ini dikarenakan kurangnya fasilitas di ruangan pelayanan seperti pendingin ruangan sehingga mengakibatkan ruang tunggu menjadi panas dan sering dikeluhkan oleh masyarakat. Berdasarkan hal tersebut, maka perlu adanya upaya untuk meningkatkan fasilitas yang berkaitan dengan kenyamanan dilingkungan pelayanan.

\section{Keamanan Pelayanan}

Nilai IKM untuk keamanan pelayanan di Kantor Disdukcapil Kota Palangka Raya adalah sebesar 2,91 dengan nilai konversi IKM sebesar 72,75. Maka berdasarkan hasil penelitian tersebut, keamanan pelayanan di Kantor Disdukcapil Kota Palangka Raya memiliki mutu pelayanan berada pada kategori "B" dan kinerja unit pelayanan "BAIK". Akan tetapi meskipun demikian masih ada beberapa masyarakat yang menganggap bahwa keamanan dilingkungan pelayanan seperti tempat parkir kendaraan masih kurang dan pelayanan yang diberikan masih belum sesuai harapan masyarakat. Berdasarkan hal tersebut, maka perlu adanya upaya untuk meningkatkan keamanan pelayanan dan meningkatkan kualitas pelayanan yang diberikan kepada masyarakat agar terwujudnya kepuasan masyarakat.

\section{KESIMPULAN}

Berdasarkan hasil penelitian dan pembahasan dapat disimpulkan bahwa hasil analisis indeks kepuasan masyarakat di Kantor Dinas Kependudukan dan Pencatatan Sipil Kota Palangka Raya yang mengacu pada Kepmenpan Nomor 25 Tahun 2004 terdiri dari 14 unsur pelayanan sebagai dasar pengukuran terhadap indeks kepuasan masyarakat. Maka diperoleh nilai IKM adalah sebesar 2,963 dan nilai konversi IKM sebesar 74,075 berada pada interval 62,51-81,25. Sehingga mutu pelayanan berada pada kategori "B" hal ini menunjukkan bahwa kinerja unit pelayanan di Kantor Dinas Kependudukan dan Pencatatan Sipil Kota Palangka Raya pada tahun 2019 berada pada kategori "BAIK". Dari 14 unsur pelayanan tersebut, unsur kewajaran biaya pelayanan merupakan unsur dengan nilai indeks tertinggi yaitu sebesar 78,75 berada pada kategori baik dikarenakan masyarakat menganggap biaya yang dibayarkan sudah sesuai dengan aturan yang berlaku. Sedangkan unsur kecepatan pelayanan merupakan unsur dengan nilai indeks terendah yaitu sebesar 67,50 berada pada kategori baik, akan tetapi sebagian masyarakat menganggap 
kecepatan pelayanan masih kurang baik karena tidak sesuai dengan target waktu pelayanan yang telah ditentukan.

\section{SARAN}

Berdasarkan kesimpulan dari hasil penelitian diatas, maka peneliti mengemukakan beberapa saran kepada Kantor Dinas Kependudukan dan Pencatatan Sipil Kota Palangka Raya sebagai berikut:

1. Kejelasan petugas pelayanan berada pada kategori baik, namun perlu diperbaiki dan ditingkatkan lagi terkait dengan jumlah petugas yang berada diloket pelayanan dan sebaiknya ada penambahan loket pelayanan untuk pelayanan yang banyak diberikan pada masyarakat hal tersebut agar memperlancar dan tidak menimbulkan antrian yang cukup panjang.

2. Kedisiplinan petugas pelayanan berada pada kategori baik, namun perlu ditingkatkan lagi yaitu terkait dengan waktu pelaksanaan pelayanan (jam buka pelayanan). Sudah seharusnya petugas mematuhi aturan yang berlaku dan perlu adanya tindak tegas apabila ada petugas yang kurang disiplin dan tidak mematuhi aturan.

3. Kecepatan pelayanan merupakan unsur pelayanan dengan nilai indeks terendah meskipun berada pada kategori baik. Sehingga perlu diperbaiki dan ditingkatkan lagi dengan mematuhi prosedur pelayanan yang berlaku.

4. Kenyamanan lingkungan berada pada kategori baik, namun perlu untuk diperbaiki dan ditingkatkan lagi berkaitan dengan sarana diruangan pelayanan seperti penambahan pendingin ruangan meskipun sudah ada namun tidak berfungsi sebagaimana mestinya dan hal ini sering dikeluhkan masyarakat karena kondisi ruangan yang dirasa masih kurang nyaman.

\section{DAFTAR PUSTAKA}

Algifari. 2016. Mengukur Kualitas Layanan Dengan Indeks Kepuasan,
Metode Importance-Performance Analysis (IPA), dan Model Kano. Yogyakarta : BPFE Yogyakarta.

Bungin, Burhan. 2005. Metodologi Penelitian Kuantitatif Komunikasi, Ekonomi, dan Kebijakan Publik Serta Ilmu-Ilmu Sosial Lainnya, Edisi 2. Jakarta : Kencana Prenada Media Group

Hardiyansyah. 2011. Kualitas Pelayanan Publik Konsep,Dimensi,Indikator dan Implementasinya. Yogyakarta : Gava Media.

Keputusan Menteri Pendayagunaan Aparatur Negara Nomor 25 Tahun 2004 tentang Pedoman Umum Penyusunan Indeks Kepuasan Masyarakat Unit Pelayanan Instansi Pemerintah.

Keputusan Menteri Pendayagunaan Aparatur Negara Nomor 63 Tahun 2003 tentang Pedoman Umum Penyelenggaraan Pelayanan Publik.

Mardiyanto, Rizka dan Mary Ismowati. 2017. Analisis Indeks Kepuasan

Masyarakat Dalam Upaya Peningkatan Kepuasan Kualitas Pelayanan Masyarakat Di Kantor Kecamatan Kotabaru Kabupaten Karawang. Jurnal Ilmiah Ilmu Administrasi, Vol. 9, No.02 (https://ojs.stiami.ac.id, diakses 27 Januari 2019).

Mukarom, Zaenal \& Muhibudin Wijaya L. 2015. Manajemen Pelayanan Publik. Bandung : CV Pustaka Setia.

Mulyadi, Deddy. 2016. Studi Kebijakan Publik dan Pelayanan Publik Konsep dan Aplikasi Proses Kebijakan Publik Berbasis Analisis Bukti Untuk Pelayanan Publik. Bandung : Alfabeta.

Singarimbun, Masri \& Sofian Effendi. 2015. Metode Penelitian Survei. Jakarta : LP3ES.

Siregar, Syofian. 2013. Metode Penelitian Kuantitatif Dilengkapi Perbandingan Perhitungan Manual 
\& SPSS. Jakarta : Kencana Prenadamedia Group.

Sugiyono. 2013. Metode Penelitian Pendidikan Pendekatan Kuantitatif, Kualitatif, dan R\&D. Bandung : Alfabeta.

Sugiyono. 2016. Metode Penelitian Kuantitatif, Kualitatif, dan $R \& D$. Bandung : Alfabeta.

Suharsaputra, Uhar. 2012. Metode Penelitian Kuantitatif, Kualitatif, dan Tindakan. Bandung : Refika Aditama.

Tjiptono, Fandy \& Chandra, G. 2011. Service, Quality \& Satisfaction, Edisi 3. Yogyakarta : Penerbit ANDI.

Undang-Undang Nomor 25 Tahun 2009 tentang Pelayanan Publik.

Winarsih, Atik Septi \& Ratminto. 2005. Manajemen Pelayanan. Yogyakarta : Pustaka Pelajar.

Zulfi Ahaditya Arif Nugraheni. 2015. Analisis Kepuasan Masyarakat Terhadap Pelayanan Publik Berdasarkan Indeks Kepuasan Masyarakat Di Kantor Kecamatan Mungkid Kabupaten Magelang. Skripsi. 